\title{
HUBUNGAN PERSEPSI SISWA MENGENAI PELAKSANAAN ASAS KERAHASIAAN OLEH GURU BK DENGAN MINAT SISWA MENGIKUTI KONSELING INDIVIDU KELAS VIII SMP NEGERI 2 AMPELGADING PEMALANG
}

\author{
Rizqi Zulfah, Heru Mugiarso \\ Jurusan Bimbingan dan Konseling Fakultas Ilmu Pendidikan \\ Universitas Negeri Semarang, Indonesia \\ 1rizqizulfa66@gmail.com., hㅡㄹㅏ.
}

\begin{abstract}
Abstrak
Layanan konseling individu merupakan salah satu layanan yang disediakan guru BK untuk membantu siswanya. Namun, layanan tersebut belum dimanfaatkan secara maksimal oleh siswa karena persepsi siswa terhadap guru BK kurang baik. Persepsi tersebut dimungkinkan dapat mempengaruhi minat siswa mengikuti layanan konseling individu. Melihat hipotesis tersebut, penelitian ini akan membahas mengenai hubungan persepsi siswa terhadap pelaksanaan asas kerahasiaan oleh guru BK dengan minat siswa mengikuti layanan konseling individu. Tujuan penelitian ini adalah membuktikan adanya hubungan persepsi siswa terhadap minat siswa. Populasi yang diteliti adalah seluruh siswa kelas VIII SMP Negeri 2 Ampelgading dengan sampel 152 orang yang dipilih secara acak (random sampling). Penelitian ini merupakan jenis penelitian expost facto. Data penelitian diambil menggunakan angket skala psikologis tentang persepsi siswa dan minat siswa. Seluruh data yang didapatkan kemudian dianalisis dan diuji menggunkan rumus korelasi produt moment. Setelah dilakukan pengujian, didapatkan kesimpulan bahwa ada hubungan persepsi siswa terhadap minat siswa. Persepsi siswa yang rendah menjadi salah satu faktor rendahnya minat siswa mengikuti konseling individu.
\end{abstract}

Kata kunci: persepsi siswa, minat siswa, konseling individu

\begin{abstract}
Individual counseling services are one of the services provided by $\mathrm{BK}$ teachers to help their students. However, these services have not been fully utilized by students because students' perceptions of BK teachers are not good. These perceptions may influence students' interest in participating in individual counseling services. Looking at this hypothesis, this study will discuss the relationship between student perceptions of the implementation of the principle of confidentiality by counseling teachers with students' interest in participating in individual counseling services. The purpose of this study was to prove the relationship between student perceptions of student interests. The population studied was all students of class VIII SMP Negeri 2 Ampelgading with a sample of 152 people who were randomly selected (random sampling). This research is an ex post facto research. The research data were taken using a psychological scale questionnaire about student perceptions and student interests. All data obtained were then analyzed and tested using the product moment correlation formula. After testing, it was concluded that there was a relationship between student perceptions of student interests. Students' low perceptions are one of the factors for the low interest of students in participating in individual counseling.
\end{abstract}

Keywords: student perceptions, student interests, individual counseling. 


\section{PENDAHULUAN}

Bimbingan sebagai bagian yang tak terpisahkan dari pendidikan dan mempunyai tanggung jawab yang besar dalam mewujudkan manusia Pancasila yang sesuai dengan tujuan dari Pendidikan Nasional. Bimbingan tidak lepas dari tujuan pendidikan nasional baik secara konseptual maupun operasional, yaitu keseluruhan upaya yang bertitik tolak dari hakikat pendidikan Nasional yakni dalam mencerdaskan kehidupan manusia, dan membantu terbimbing dalam mewujudkan diri sebagai manusia Pancasila.

Pengertian bimbingan sendiri adalah proses pemberian bantuan yang dilakukan oleh seorang ahli kepada individu dengan menggunakan berbagai prosedur, cara dan bahan agar individu tersebut mampu mandiri dalam memecahkan masalah-masalah yang dihadapinya, sedangkan konseling merupakan proses pemberian bantuan yang didasarkan pada prosedur wawancara konseling oleh seorang ahli kepada yang bermuara pada teratasinya masalah yang dihadapi klien.

Selain itu tujuan dari Bimbingan dan Konseling adalah untuk membantu individu agar dapat mencapai perkembangan secara optimal sesuai dengan bakat, kemampuan, minat dan nilai-nilai, serta terpecahkannya masalah-masalah yang dihadapi individu. Oleh karena itu, tujuan diadakannya layanan bimbingan dan konseling ini adalah agar individu yang memperoleh layanan ini dapat lebih mandiri dalam memecahkan masalah yang dihadapinya dan berani bertanggung jawab atas tindakan-tindakan yang dilakukannya.

Layanan konseling individu merupakan salah satu layanan yang disediakan guru BK untuk membantu siswanya. Konseling individu berupa proses pemberian bantuan yang dilakukan melalui wawancara konseling oleh seorang ahli (konselor) kepada individu yang sedang mengalami suatu masalah (klien) yang bermuara pada teratasinya masalah yang dihadapi klien. Layanan ini bertujuan untuk memberikan bantuan kepada siswa khususnya untuk melakukan pengentasan masalah yang dialami siswa. 
Keberadaan layanan konseling individu sebenarnya akan sangat membantu siswa jika siswa dapat memanfaatkan dengan baik. Namun, hingga saat ini layanan tersebut belum dimanfaatkan secara maksimal oleh siswa. Masih banyak siswa yang enggan melakukan konseling individu dengan beragam alasan mulai dari adanya pengalaman negatif tentang guru BK dan pelayanan konseling yang belum sesuai harapan. Selain itu, banyak siswa yang khawatir jika masalah yang mereka anggap sebagai rahasia tidak bisa dijaga dengan baik oleh guru BK. Keadaan tersebut harus segera diperbaiki agar persepsi tersebut tidak terus menerus berkembang di benak siswa sehingga menyebabkan siswa enggan melakukan konseling individu.

Persepsi menjadi salah satu penentu minat dan tingkah laku siswa. Persepsi yang kurang baik dimungkinkan dapat memberikan pengaruh buruk terhadap minat dan tingkah laku siswa. Hipotesis tersebut perlu diketahui hubungannya agar jika memang benar persepsi siswa mempengaruhi minat mengikuti layanan konseling, pihak-pihak terkait khususnya guru BK dapat memperbaiki diri sehingga siswa lebih berminat untuk mengikuti konseling individu.

\section{METODE}

Penelitian ini merupakan penelitian expost facto. Expost facto merupakan penelitian dimana vaiabel-variabel bebas telah terjadi ketika peneliti mulai dengan pengamatan variabel terikat dalam suatu penelitian (Sukardi, 2013:165). Proses penelitian ini dimulai dengan pengamatan variabel bebas yang telah muncul. Kemudian dilanjutkan dengan pengamatan terhadap variabel terikat. Hubungan dan keterkaitan antar variabel yang sudah terjadi kemudian berusaha dilacak kembali oleh peneliti untuk mengetahui apakah terdapat hubungan diantara keduanya.

Populasi yang ingin diteliti adalah seluruh siswa kelas VIII SMP Negeri 2 Ampelgading. Namun, mengingat keterbatasan waktu diambil sampel penelitian secara acak (random sampling) sebanyak 5\% dari seluruh populasi sehingga diperoleh sampel 152 siswa. Seluruh sampel kemudian mengisi angket skala persepsi siswa mengenai pelaksanaan asas kerahasiaan oleh guru BK yang terdiri atas 50 poin pernyataan dengan rincian 25 poin pernyataan positif dan 25 poin pernyataan negatif. Setelah selesai mengisi angket tersebut, seluruh sampel siswa kemudian mengisi angket skala minat siswa mengikuti konseling individu. Angket skala minat siswa tersebut terdiri atas 50 poin pernyataan dengan rincian 28 poin pernyataan positif dan 22 poin pernyataan negatif. Sebelum diisi siswa, kedua angket tersebut telah diuji validitas dan reliabilitasnya.

Setelah seluruh sampel penelitian mengisi dua angket, dilakukan penghitungan hasil angket. Penghitungan tersebut menghasilkan data persepsi siswa dan data minat siswa. Kedua data tersebut kemudian dianalisis menggunakan metode analisis deskriptif kuantitatif, 
uji asumsi, uji normalitas, uji linearitas, analisis korelasi, dan uji regresi sederhana. Seluruh uji tersebut dilakukan secara berurutan.

\section{HASIL}

Sesuai dengan tujuan penelitian yaitu untuk mengetahui hubungan antara persepsi siswa mengenai pelaksanaan asas kerahasiaan yang dilakukan guru BK dan minat siswa untuk mengikuti konseling individu, berikut akan disampaikan hasil penelitian mengenai halhal tersebut.

\section{Persepsi Siswa Mengenai Pelaksanaan Asas Kerahasiaan Oleh Guru BK}

Persepsi merupakan suatu proses penginderaan didahului dengan proses diterimanya stimulus oleh individu melalui alat indera atau juga disebut proses sensoris (Walgito, 2003:99). Setelah dilakukan proses penerimaan stimulus, stimulus kemudian diproses menjadi persepsi untuk kemudian dilanjutkan menjadi respon sehingga persepsi mempengaruhi respon individu terhadap sesuatu. Pada penelitian ini, peneliti ingin mengetahui persepsi siswa mengenai pelaksanaan asas kerahasiaan oleh guru BK. Setelah dilakukan penghitungan hasil angket skala persepsi siswa mengenai pelaksanaan asas kerahasiaan oleh guru BK dan dilakukan serangkaian proses analisis data didapatkan data sebagai berikut.

\section{Tabel 4.1 Hasil Analisis Persepsi Siswa}

\begin{tabular}{clll}
\hline Variabel & \multicolumn{1}{c}{ Indikator } & Mean & Ketegori \\
\hline Persepsi & Menghargai hak siswa & 2,53 & Rendah \\
siswa & Kerahasiaan informasi & 1,67 & Rendah \\
& Rekaman data siswa & 2,20 & Rendah \\
& Total & 2,13 & Rendah \\
\hline
\end{tabular}

Berdasarkan tabel tersebut dapat diketahui bahwa persepsi siswa mengenai pelaksanaan asas kerahasiaan oleh guru BK sebesar 2,13. Angka tersebut menunjukkan bahwa persepsi siswa mengenai pelaksanaan asas kerahasiaan oleh guru BK tergolong rendah.

\section{Minat Siswa Mengikuti Konseling Individu}


Minat merupakan perasaan tertarik untuk melakukan sesuatu. Minat menjadi sumber motivasi yang mendorong orang untuk melakukan apa yang mereka inginkan bila mereka bebas memilih (Hurlock, 2013:114). Selain itu, minat juga merupakan rasa lebih suka dan rasa keterkaitan pada suatu hal atau aktifitas, tanpa ada yang menyuruh (Djaali, 2006:121). Pada penelitian ini, peneliti ingin mengetahui minat siswa mengikuti konseling individu. Siswa mengisi angket skala psikologis minat siswa mengikuti konseling individu kemudian data dari angket tersebut dianalisis. Hasil analisis data tersebut adalah sebagai berikut.

Tabel 4.2 Hasil Analisis Minat Siswa Mengikuti Konseling Individu

\begin{tabular}{llcc}
\hline \multicolumn{1}{c}{ Variabel } & \multicolumn{1}{c}{ Indikator } & Mean & Kategori \\
\hline Minat siswa & Sikap & 2,28 & Rendah \\
mengikuti & Motivasi diri & 1,96 & Rendah \\
konseling & Adanya masalah yang timbul & 2,12 & Rendah \\
individu & Keluarga & 2,20 & Rendah \\
& Guru BK & 1,82 & Rendah \\
& Fasilitas & 1,63 & Rendah \\
& Teman pergaulan & 2,18 & Rendah \\
& Total & $\mathbf{2 , 0 2}$ & Rendah \\
\hline
\end{tabular}

Berdasarkan tabel tersebut, dapat diketahui bahwa minat siswa mengikuti konseling individu termasuk dalam kategori rendah yaitu sebesar 2,02.

\section{Hasil Uji Hubungan antara Persepsi Siswa mengenai Pelaksanaan Asas Kerahasiaan dengan Minat Siswa Mengikuti Konseling Individu}

Guna mengetahui hubungan antara persepsi siswa dengan minat siswa maka digunakan rumus uji korelasi product moment dengan bantuan SPSS versi 21.0. Setelah dilakukan uji, didapatkan data sebagai berikut.

Tabel 4.3 Hasil Uji Korelasi Product Moment

\begin{tabular}{|rl|r|r|}
\hline \multicolumn{4}{c|}{ Correlations } \\
\hline \multirow{4}{*}{ Persepsi } & Persepsi siswa & Minat \\
& Pearson Correlation & 1 & $.222^{*}$ \\
& Sig. (2-tailed) & & .013 \\
& $\mathrm{~N}$ & 123 & 123 \\
& Pearson Correlation & $.222^{*}$ & 1 \\
Minat & Sig. (2-tailed) & .013 & \\
& $\mathrm{~N}$ & 123 & 123 \\
\hline
\end{tabular}

*. Correlation is significant at the 0.05 level (2-tailed). 
Berdasarkan tabel 4.3 dapat dilihat bahwa sig $=0,013$ kurang dari $5 \%$ maka dapat disimpulkan bahwa hipotesis awal terbukti. Hasil uji korelasi product moment tersebut menegaskan bahwa ada hubungan antara persepsi siswa mengenai pelaksanaan asas kerahasiaan oleh guru BK dengan minat siswa melakukan konseling individu.

\section{PEMBAHASAN}

Penelitian ini dilakukan untuk mengetahui hubungan antara persepsi siswa mengenai pelaksanaan asas kerahasiaan oleh guru BK dan minat siswa mengikuti konseling individu. Hipotesis penelitian ini adalah ada hubungan antara persepsi siswa dengan minat siswa mengikuti layanan konseling individu.

Berdasarkan hasil yang diperoleh peneliti, diketahui bahwa gambaran persepsi siswa mengenai pelaksanaan asas kerahasian oleh guru BK pada kategori rendah. Artinya persepsi siswa mengenai pelaksanaan asas kerahasiaan oleh guru BK belum baik dan siswa belum percaya kepada guru BK. Siswa masih belum percaya bahwa guru BK dapat menjaga rahasia yang mereka ceritakan.

Setelah dilakukan analisis, diketahui bahwa seluruh indikator persepsi siswa menunjukkan nilai rendah. Pada indikator pertama yaitu menghargai hak siswa, didapatkan rata-rata 2,53. Pada indikator kedua yaitu kerahasiaan informasi didapatkan rata-rata 1,67, sedangkan pada indikator ketiga yaitu rekaman data siswa didapatkan rata-rata 2,20. Ketiga rata-rata tersebut tergolong kategori rendah. Keadaan tersebut tentu mengkhawatirkan mengingat persepsi siswa mengenai asas kerahasiaan merupakan salah satu penentu utama bagi siswa untuk melakukan konseling individu. Walgito (2003) menyatakan bahwa persepsi merupakan suatu proses pengindraan yang dimulai dengan proses diterimanya stimulus oleh individu melalui alat indera atau juga disebut proses sensoris. Stimulus tersebut kemudian diteruskan dan menentukan respon atau tingkah laku individu. Jika sejak awal persepsi siswa 
rendah maka dimungkinkan respon siswa juga rendah sehingga siswa kurang berminat mengikuti kegiatan konseling individu.

Selanjutnya berdasarkan data angket skala psikologis minat siswa melakukan konseling individu, didapatkan hasil analisis bahwa minat siswa mengikuti konseling individu tergolong rendah. Sebelumnya siswa mengisi angket berisi 50 poin pernyataan yang berkaitan dengan tujuh indikator penentu motivasi siswa. Data yang didapatkan dari angket tersebut kemudian dianalisis dan didapatkan rata-rata yang beragam. Pada indikator pertama yaitu sikap, didapatkan rata-rata 2,28. Kemudian pada indikator kedua yaitu motivasi diri didapatkan rata-rata 1,96 dan pada indikator ketiga yaitu adanya masalah yang timbul didapatkan rata-rata 2,12. Pada indikator keempat yaitu keluarga didapatkan rata-rata sebesar 2,20 dan pada indikator kelima yaitu guru BK didapatkan rata-rata 1,82. Pada indikator keenam yaitu fasilitas, didapatkan rata-rata 1,63 dan pada indikator ketujuh yaitu teman pergaulan didapatkan rata-rata 2,18 . Seluruh rata-rata tersebut tergolong kategori rendah dan artinya siswa kurang berminat mengikuti konseling individu bersama guru BK.

Kemudian, setelah dilakukan uji korelasi product moment terhadap data persepsi siswa mengenai pelaksanaan asas kerahasiaan oleh guru BK dan data minat siswa mengikuti layanan konseling individu diketahui bahwa ada hubungan yang signifikan antara persepsi siswa dengan minat siswa mengikuti konseling. Persepsi siswa yang awalnya sudah rendah memiliki keterkaitan dengan minat siswa yang juga rendah. Persepsi siswa yang rendah terbukti memberikan dampak terhadap minat siswa mengikuti konseling individu bersama guru BK. Meski demikian, persepsi tidak menjadi satu-satunya faktor yang dapat mempengaruhi minat siswa. Masih ada faktor lain yang mungkin dapat mempengaruhi minat siswa.

Hal-hal yang dapat membuat persepsi siswa rendah harus segera diatasi oleh pihakpihak terkait agar pelayanan konseling individu dapat berlangsung secara maksimal dan siswa dapat memanfaatkan layanan tersebut dengan baik. Salah satu cara yang dapat dilakukan untuk meningkatkan minat siswa mengikuti konseling individu bersama guru BK adalah guru BK perlu menumbuhkan minat siswa mengikuti konseling individu melalui 
berbagai hal menarik sehingga guru BK juga perlu meningkatkan keterampilan dalam menumbuhkan minat siswa. Selain itu, guru BK juga perlu menjaga hubungan baik dengan siswa mengingat hasil penelitian Agus Hadi Cahyono (2013) bahwa siswa yang berminat mengikuti konseling disebabkan oleh beberapa faktor antara lain pengalaman negatif siswa terhadap BK yaitu pelayanan yang tidak sesuai dengan harapan siswa, pandangan bahwa guru BK merupakan polisi sekolah, dan kesan yang sering timbul bahwa berurusan dengan guru BK berarti memiliki masalah yang tidak baik. Faktor-faktor tersebut perlu dihindari dan diperbaiki oleh guru BK agar minat siswa melakukan konseling individu dapat meningkat.

\section{SIMPULAN}

Berdasarkan hasil penelitian dan pembahasan mengenai hubungan antara persepsi siswa mengenai pelaksanaan asas kerahasiaan oleh guru BK dan minat siswa mengikuti layanan konseling individu didapatkan kesimpulan bahwa persepsi siswa menjadi salah satu faktor yang mempengaruhi minat siswa. Persepsi siswa terhadap pelaksanaan asas kerahasiaan oleh guru BK yang rendah menyebabkan minat siswa untuk mengikuti layanan konseling pribadi juga rendah. Meski demikian, persepsi tidak menjadi satu-satunya faktor yang mempengaruhi minat siswa.

\section{DAFTAR PUSTAKA}

Achmad Juntika Nurihsan. 2007. Strategi Layanan Bimbingan \& Konseling. Bandung: Refika Aditama.

Djaali .(2008). Psikologi Pendidikan. Jakarta: Bumi Aksara.

Hurlock, Elizabeth B. (2000). Perkembangan Anak Jilid 1 (diterjemahkan oleh Meitasari dan Muslichah). Jakarta: Erlangga.

Marsudi, dkk. (2003). Layanan Bimbingan Konseling di Sekolah. Surakarta: Muhammadiyah University Press.

Prayitno \& Erman Amti. (1999). Dasar-Dasar Bimbingan dan Konseling. Jakarta: Rineka Cipta.

Sugiyono. (2014). Metode Penelitian Pendidikan: Pendekatan Kuantitatif, Kualitatif, dan $R \& D$. Bandung: Alfabeta. 